Vol. 2, No. 2, 2020

339.138:303.214.3

U. O. Balyk, M. V. Kolisnyk,

Lviv Polytechnic National University

Kyiv School of Economics

\title{
COMPARISON OF PREDICTIVE VALIDITY OF A FOCUS GROUP AND COGNITIVE MARKETING METHODS
}

http://doi.org/

(C) Balyk U. O., Kolisnyk M. V., 2020

The article examines topicality and peculiarities of using neuromarketing methods. The potential of a focus group method and latest achievements in cognitive neuromarketing are described. Food tasting has been used to make a comparative evaluation of the predictive validity of a classic neuromarketing method - focus groups and up-to-date cognitive neuromarketing methods. In particular, neuromarketing methods have been used to carry out the analysis of the test participants' cognitive and emotional indicators (stress, engagment, interest, excitement, focus, relaxation), which had been obtained during observation, sniffing at, tasting (chewing) and aftertaste sensation of the food. This test made it possible to draw conclusions based on gender differences about each stage of the test participant's interaction with the food (appearance, smell, taste, aftertaste). Cognitive neuromarketing and a focus group methods have been used to analyze the test participant's responses to the tasting process itself (food staying in a mouth). On the basis of the study results and with regard to gender differences the information about significance of the food taste properties, their weaknesses and possibilities to improve them has been obtained. The influence of gender on the study results in the group has been investigated using the focus group method.

Kee words: neuromarketing, behaviour economic, customers, marketing methods

\section{Introduction}

Any producer needs to constantly increase sales volume. The whole complex of marketing measures helps to do that - starting from demand estimation, a product or a service creation, arranging of promotion and other. Under conditions of a fierce world competition, it is not enough to simply create a good quality product with aesthetic and media support. It is necessary that an advertising message, information about usefulness of a product/service and a design form a constructive dialogue with a customer: draw attention to a concrete product/service/idea among all the others, positively impress with how a brand has won the trust in a producer, encourage multiple purchase and spreading positive information about this product/service among other people.

When the advertising budget is reduced a marketing specialist has to succeed at the first attempt as there might be no resources for the second one. It is necessary to build up a strategy which will make it possible not only to recoup the investments but also to market your brand, however not the whole category of the products and not your competitors at the same time (Stewart, \& Shamdasani, 2014). It is a very difficult task - to develop a selective choice in your customers.

Professionals are well aware of the Fairfax Cone's idea that there is no collective consciousness, the crowd consists of individuals, therefore a good advertisement is always a message of one person to another, and the advertisement targeted at everyone hits no one (Lewis, 2013). To implement this 


\section{Balyk U. O., Kolisnyk M. V.}

conception and to draw the conclusions marketing specialists are using methods of studying customer's thoughts about the product/service which were formed as early as 70s of the 20th century (focus groups, surveys, observations, tests) (Kamberelis, \& Dimitriadis, 2013).

At the same time at present the aforementioned methods raise some doubts about reasonability of their usage as often the conclusions drawn on the basis of this study were plausible, but still erroneous. This causes damages to a producer as well as provokes despair and confusion of marketing specialists. Many question arise: "What did we miss? What did we do wrong? What should we do not to let this situation happen again?". Until 70-s of the 20th century marketing and economic theory had very simple ideas about a customer's behavior as they did not take into consideration psychologists' researches about individual and collective human behavior. Besides, ignoring the knowledge about unconscious processes of the human psyche encouraged the wrong idea that people know and understand "exactly" which psychic mechanisms are engaged in their making decisions and taking actions. When new products were being marketed there were constant disputes and heated discussions at the companies and as a result everyone acted on their discretion or according to the senior manager's order (Finch, \& Lewis, 2003). Marketing specialists did not fully understand business realities (Zurawicki, 2010). Under the conditions of new economic reality, conservatism and formation of marketing processes based on many years of the collective work experience led to bankruptcy and disappearance of many companies.

The last century marketing problems resulted from relying on a marketing specialist's subjective estimation of the situation at the market. Everyone has his or her own and unique reality because it is determined by the limitations of perception, cognitive distortions and individual life experience which form stereotypical thinking and attachment to a culture a person belongs to (Kenrick, \& Griskevicius, 2013). For example, a human perceives only 1/ 12000000 part of frequencies existing in nature and creates a picture of the world, including economic reality, on the basis of this supernarrow interval. Besides, in everyday life and professional activity a human mostly uses (98\%) heuristic (simple and fast thinking with wrong conclusions) instead of expert thinking (a complex one based on the knowledge about psychological peculiarities of a human with the usage of empirical data and application of traditional and symbolic logic) (Morin, 2011). Therefore, the marketing specialists' predictions about the market based on a subjective impression were extremely incorrect.

For a long period it has been believed that sociological studies have a high external validity. However, the elections on the 8th of November, 2016, in the USA shook this belief and preconditioned reconsidering of the electoral paradigm. Despite the sociologists predicted the victory of Hillary Clinton, Donald Trump won the election. It happened because often people declare one preference for the survey while having a completely different one. In 2018 in Ukraine a study of the electorate's unconscious responses to political slogans in external advertising was conducted with the usage of the latest neuromarketing methods (Maksymenko, Tkach, Lytvynchuk, \& Onufriieva, 2019). The results of the study are impressive as 4 months prior to the elections it was known what places would be taken by the presidential candidates. Moreover, it had been predicted before one of the main candidates officially declared that he would take part in the elections.

Modern marketing specialists understand it well that neuromarketing is the key to profitability of a company as it helps to clearly understand the client and to transform his/her needs into an attractive product. For an advertisement testing, design and even convenient usage the following methods neuromarketing study are used: eye tracking, emotions recognition system, electroencephalography, measurement of the electrodermal activity, electromyography, functional magnetic resonance imaging, psychodiagnostics/neuropsychodiagnistics.

Eye tracking is carried out with the help of an eye tracker, which observes eyes movement and the reaction to what is seen (video, photo, real conditions) and it also can determine a gaze direction. This can tell what is the first thing a customer pays attention to and what he/she is really attracted by. However, 
there is also a covert attention: when a person misses an object and does not look at it on purpose. For example, when a shy young man sees an attractive girl. And marketing specialists are aware of many such details. On the basis of peculiarities and speed of eyes movement it is possible to determine intrapsychic activity of an examined person and also to tell if he/she is interested in the picture (Holmqvist, \& Andersson, 2017).

Emotions recognition system reads mimics of a human face and assists in recognition of human emotion at a distance. Human reactions on a certain situation or object can be absolutely different - we can feel happiness, fear, disgust and many other emotions expressed by our face. It is important that face emotions appear faster than we can realize them (Fathima, \& Vaidehi, 2020). However, due to cultural (regional) aspects of emotions expression an additional expert evaluation by a psychologist belonging to this "cultural" group is applied.

Electroencephalography (EGG) helps to make an objective evaluation of the emotional reaction on a suggested stimulus and also to predict a choice out of few possible options. Scientists can predict not only "the desire to buy" but also what exact choice a person will make 9 seconds prior to realizing his/her desire, and then he or she will take action. On the basis of EEG the interface brain-computer is created - it is a new paradigm of studying a brain within neurosciences (Aldayel, Ykhlef, \& Al-Nafjan, 2020). With the help of a complex examination of the brain signals and search of specific EEG partners it is possible to find out: concentration of attention level, stress level, worry, relaxation, readiness of a person to act in a certain situation (for example, in an office, in a shop) or during the meeting with your product or service (Yadava, Kumar, Saini, Roy, \& Dogra, 2017).

Thanks to electrodermal activity it is possible to track emotional arousal and to determine the stress level. A human body can't deceive itself, it honestly reacts. Sometimes these reactions are called "inner senses". For example, this method is used to analyze a person's condition and his/her reaction to a certain service or product.

Electromyography helps to diagnose bioelectrical potentials during muscle fibers contractions. This method it especially informative for making a decision when there is a conflict between logical and emotional brain systems, we can monitor muscles tension and hormones secreting into the blood (Phinyomark, Campbell, \& Scheme, 2020).

Electromyography makes it possible to detect inner/hidden response of a person to a certain stimulus, what, in fact, helps to understand to what extent the person is satisfied or unsatisfied (Dzedzickis, Kaklauskas, \& Bucinskas, 2020).

Functional magnetic resonance imaging analyses the activity of different brain structures during the contact with a stimulus. This information helps to understand which advertising campaigns are effective for a consumer and which predetermine "right" emotions, encourage to take actions (Walsh, Deseniss, \& Kilian, 2020).

Psychodiagnostics/neuropsychodiagnistics enables segmentation of customers/voters and elaboration of an individual approach. A world-famous company "Cambridge Analytica" specializing in behavior correction introduced an individual approach and demonstrated in real life the effectiveness of psychodiagnostics in political neuromarketing - this is Brexit, electing Trump and other campaigns in about thirty countries.

Methods of reading electric potentials can tell an exact time of a person's response, though they will tell a rather approximate location of the response in the brain. Functional magnetic resonance imaging cannot determine the response so quickly, but it finds an exact location of activity (hemodynamic response) in the brain, which is connected with this behavior response. Other methods of studying the brain are auxiliary and specifying, they enable deciphering of the whole tremendous amount of research data.

Every neuromarketing method has certain advantages and technical limitations, therefore, in practice a few methods are combined depending on a technical task. In particular, neuropsychodiagnostics, eye 


\section{Balyk U. O., Kolisnyk M. V.}

tracking and electroencephalography give marketing specialists reliable results while testing a packing design. It is desirable to also apply emotions recognition system for testing of video advertising (film). If it is impossible to apply emotions recognition system the studies of electrodermal activity and/or electrocardiography are used.

All the aforementioned methods of cognitive neuromarketing study give a producer a clear and understandable feedback from a customer - where in the brain a button "buy it" is located.

Neuromarketing leaves behind all the other approaches which are not based on scientific data but on a personal experience. A scientific approach, which forms the knowledge about the reasons why do people buy what they buy, makes a modern marketing specialist the main figure at the office (Lyapina, Uvarova, Sibirskaya, Pashkevich, \& Tikhoykina, 2020). Therefore, nowadays it is important to determine predictive validity of a "classic" method - a focus group and "the latest" ones - cognitive neuromarketing methods. Predictive validity of a method identifies an extent to which this method can predict future popularity (great or small) of a product. If a method can do this task, its usage is considered to be reasonable and effective in helping marketing specialists to avoid mistakes which lead to wrong management decisions.

The aim of the article is to make a comparison of predictive validity of a focus group method and cognitive marketing methods.

\section{Research method}

General scientific methods of theoretical and empirical study were applied to reach the aim of the research: analysis, comparison and generalization of the information from expert literature and empirical comparison of possibilities of a traditional marketing method - a focus group and neuromarketing method - identifying unconscious reactions of customers with the help of neurointerface. The study was conducted in 2020 in Lviv, Ukraine. There were 24 men and 24 women aged from 18 to 25 taking part in the study. They were selected by a stochastic method out of the supermarket customers. The object of the study was the evaluation of dark chocolate and rye bread by the respondents. The study was conducted with the help of technical support "The First Neuromarketing Company in Ukraine Neuro Psy Tech Group". 14-channel neurointerface EMOTIV Eros+ and the software for the brain cartography and process monitoring EmotivPRO were used during the study in order to detect emotional and cognitive indicators of the brain activity.

Neuromarketing testing of each participant took 5 minutes. This includes time of communication between a brain and the computer and the tasting process itself. In total, 6 hours were spent on the whole neuromarketing study.

The test participants were divided in four groups with twelve respondents in each of them. The first group consisted of men only, the second of women, the third and the fourth groups had even numbers of men and women. The groups were formed in such a way so that it can be possible to display the influence of gender in a group on results of the study. The duration of testing was 3 hours for each group. In total, this method took 12 hours.

There were no cooks, managers, marketing specialists, sellers, psychologists and clergymen. The participants had never taken part in neuromarketing testing and a focus group before. This was made to ensure purity of the experiment and to minimize appearance of a thought leader in a group, what leads to leveling the thoughts of the other participants.

First, the test participants rinsed their mouths with water and then they tasted bread, at the same time their unconscious responses were recorded with the help of EEG. The same procedure was used to study the response to the dark chocolate.

Information about the products which were used to compare the potential of neuromarketing methods and "classic" marketing. The chocolate was dark, natural, with small amount of the chili pepper. This was not a brand chocolate, but is was specially made for the testing by a chocolatier at a 
restaurant. The rye bread also was not a product of any particular brand, it was baked at the same restaurant specially for the testing.

\section{Findings}

On the basis of neuromarketing study there was obtained a huge amount of data about the dynamics of cognitive and emotional indicators during observation, sniffing at, tasting (chewing), aftertaste sensations of the test participants. Thus, the transformation of the raw EEG data in the program EmotivPRO (Insight, 2020) there was obtained information about these six main cognitive and emotional indicators (table 1):

Table 1

The estimation of the main cognitive and emotional indicators of tasting the rye bread and the black chocolate

\begin{tabular}{|c|c|c|c|c|c|c|}
\hline \multirow[b]{2}{*}{$\begin{array}{l}\frac{n}{0} \\
\stackrel{0}{0} \\
0 \\
0\end{array}$} & \multirow[b]{2}{*}{$\overbrace{0}^{0}$} & \multirow[b]{2}{*}{ 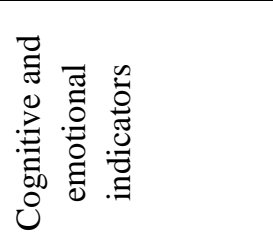 } & \multicolumn{4}{|c|}{ The stages of tasting the products } \\
\hline & & & 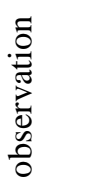 & 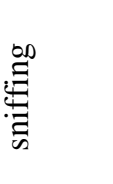 & 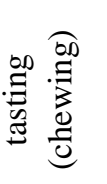 & 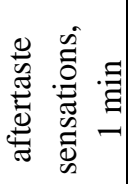 \\
\hline \multirow{12}{*}{ 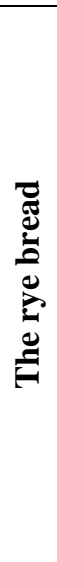 } & \multirow[t]{6}{*}{ men } & Stress & 5.02 & 12.55 & 31.80 & 7.58 \\
\hline & & Engagment & 63.57 & 68.27 & 50.73 & 32.21 \\
\hline & & Interest & 48.02 & 49.44 & 48.66 & 50.04 \\
\hline & & Excitement & 11.36 & 63.82 & 44.85 & 13.82 \\
\hline & & Focus & 51.48 & 49.30 & 30.83 & 41.86 \\
\hline & & Relaxation & 48.27 & 51.64 & 66.04 & 73.57 \\
\hline & \multirow[t]{6}{*}{ women } & Stress & 7.42 & 32.92 & 48.71 & 12.07 \\
\hline & & Engagment & 75.31 & 89.88 & 62.21 & 44.12 \\
\hline & & Interest & 74.86 & 89.38 & 57.65 & 53.80 \\
\hline & & Excitement & 33.61 & 69.00 & 62.75 & 23.45 \\
\hline & & Focus & 67.25 & 87.20 & 43.91 & 57.92 \\
\hline & & Relaxation & 44.35 & 72.57 & 78.36 & 80.83 \\
\hline \multirow{12}{*}{ 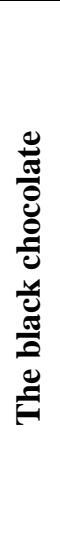 } & \multirow[t]{6}{*}{ men } & Stress & 7.47 & 10.63 & 43.58 & 33.27 \\
\hline & & Engagment & 35.41 & 58.27 & 84.58 & 86.87 \\
\hline & & Interest & 47.50 & 48.08 & 78.53 & 60.27 \\
\hline & & Excitement & 7.51 & 8.63 & 78.26 & 78.61 \\
\hline & & Focus & 48.80 & 48.02 & 59.71 & 60.13 \\
\hline & & Relaxation & 51.68 & 50.04 & 43.50 & 34.28 \\
\hline & \multirow[t]{6}{*}{ women } & Stress & 6.51 & 41.89 & 62.05 & $\mathbf{5 7 . 5 1}$ \\
\hline & & Engagment & 42.09 & 76.53 & 73.81 & 75.66 \\
\hline & & Interest & 56.61 & 60.33 & 65.40 & 62.76 \\
\hline & & Excitement & 12.94 & 14.28 & 71.58 & 67.77 \\
\hline & & Focus & 58.99 & 62.00 & 67.87 & 65.29 \\
\hline & & Relaxation & 49.83 & 51.94 & 22.46 & 10.57 \\
\hline
\end{tabular}

Source: own processing in EmotivPRO

1) stress shows how uncomfortable it is and how the body is mobilized when a person is faced with a current problem/product/service;

2) engagment determines the extent to which a person is preoccupied with what he/she is doing or concerned with it, that is how important something is; 


\section{Balyk U. O., Kolisnyk M. V.}

3) interest shows how much people like or dislike something;

4) excitement displays the level of emotional arousal (agiotage);

5) focus displays the ability to focus on one task and ignore distractions, that is how much attention the object draws;

6) relaxation shows the level of calmness of the mental state.

On the basis of the results obtained the conclusions about each stage of interaction of the test participants with the food products were drawn:

Appearance. The women displayed higher levels of interaction, interest and concentration what shows that women pay more attention than men to the appearance of the product. This was the case with both the chocolate and the bread. However, the appearance of the bread they liked more than the appearance of the chocolate.

Smell. The levels of all the indicators are higher while sniffing at the bread than while sniffing at the chocolate. Moreover, all levels are higher for the women as compared to the men. It means that women pay more attention to the smell of the food.

Taste. The levels of all indicators are higher for women than for men while tasting the bread, what means that the women liked the bread more. However, while tasting the chocolate the men displayed higher levels of indicators of interaction, interest, worry and relaxation. This means that men liked the chocolate more.

Aftertaste. After the tasting the women displayed higher levels than men of all the indicators, what shows that they liked the bread more. Meanwhile, after tasting of the chocolate the men had higher levels of indicators of interaction, worry and relaxation. This means that they like the chocolate's aftertaste. Besides, the analysis of the indicators shows that sensation of the chocolate aftertaste is more stable than the bread's one.

It is important to mention that in the process of the testing the women pay more attention to the smell sensations, are highly concentrated on the products and prefer mild tastes to quite spicy ones.

The usage of the cognitive nueromarketing method helps the producer to objectively evaluate a definite reaction of customers on the product and to confidently work with "a palette of smell, tastes, aftertaste" and appearance to improve the product.

In addition, there are three important questions marketing specialists need to get answers to: significance of taste properties of the food products; weaknesses of the food products; what can enhance the properties of the food products. Thus, indicators directly connected with the process of tasting (food staying in a mouth) were singled out with the help of the chi-square statistic (table 2).

The following conclusions have been reached on the basis of the conducted neuromarketing study:

1. About the significance of taste properties of the food products. Men like dark chocolate more than women. The men comparing to the women displayed higher levels of interaction, interest, emotional arousal and relaxation and at the same time caused less stress. Besides, this chocolate provoked lower level of concentration what points at the familiar organoleptic properties of the product. The women liked more the rye bread as comparing to the men they displayed higher levels of all cognitive and emotional indicators.

2. Weaknesses of the food products. The weakness of the bread for men was its mild taste. Meanwhile, the weakness of the chocolate for women was its too spicy ingredient - the chili pepper.

3. What can enhance the properties of the food products. Adding some spices can make the bread more attractive to men. And attractiveness of the chocolate among women can be increased by making the taste less spicy and adding an ingredient with a mild taste.

Let us shift to the quality method of the study - a focus group. The interviewer and moderator suggested to taste separately the bread and the chocolate and to discuss taste sensations of the products, in particular what tastes better. Afterwards, the communication was mostly between the respondents and the 
only thing the moderator did was making sure the conversation flows in the right direction: "When you saw the products for the first time what did you pay attention to? Why did you prefer one product to another: because of its appearance, smell, taste, aftertaste? How can you characterize the food product you like and the one you ignore?"

Table 2

The estimation of the main cognitive and emotional indicators of tasting (finding food in the mouth) the rye bread and the black chocolate

\begin{tabular}{|c|c|c|c|c|c|c|c|c|c|c|c|c|}
\hline & \multicolumn{2}{|c|}{ Stress } & \multicolumn{2}{|c|}{ Engagment } & \multicolumn{2}{|c|}{ Interest } & \multicolumn{2}{|c|}{ Excitement } & \multicolumn{2}{|c|}{ Focus } & \multicolumn{2}{|c|}{ Relaxation } \\
\hline & $\mathrm{m}$ & $\mathrm{w}$ & $\mathrm{m}$ & $\mathrm{w}$ & $\mathrm{m}$ & $\mathrm{w}$ & $\mathrm{m}$ & W & $\mathrm{m}$ & $\mathrm{w}$ & $\mathrm{m}$ & $\mathrm{w}$ \\
\hline \multirow{3}{*}{ 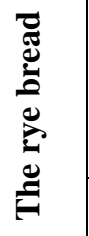 } & $\stackrel{\infty}{\infty}$ & $\vec{\nabla}$ & $\stackrel{m}{\overparen{R}}$ & $\overline{\widetilde{v}}$ & $\stackrel{8}{\circ}$ & 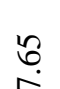 & ڤ & $\stackrel{n}{i}$ & $\infty$ & $\bar{a}$ & ț. & గొ \\
\hline & & & & & & & & & & & & \\
\hline & \multicolumn{2}{|c|}{$\mathrm{p} \leq 0.01$} & \multicolumn{2}{|c|}{$\mathrm{p} \leq 0.01$} & \multicolumn{2}{|c|}{$\mathrm{p} \leq 0.05$} & \multicolumn{2}{|c|}{$\mathrm{p} \leq 0.001$} & \multicolumn{2}{|c|}{$\mathrm{p} \leq 0.01$} & \multicolumn{2}{|c|}{$\mathrm{p} \leq 0.001$} \\
\hline \multirow{2}{*}{ 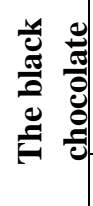 } & $\begin{array}{l}\infty \\
\dddot{r} \\
\tilde{F}\end{array}$ & $\begin{array}{l}\stackrel{2}{0} \\
i \\
0\end{array}$ & $\begin{array}{l}\infty \\
\stackrel{\infty}{\infty} \\
\infty\end{array}$ & $\begin{array}{l}\vec{\infty} \\
\stackrel{\sim}{\sim}\end{array}$ & $\begin{array}{l}\tilde{n} \\
\infty \\
\infty\end{array}$ & $\begin{array}{l}9 \\
\qquad \dot{b}\end{array}$ & 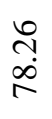 & $\stackrel{\substack{n \\
n}}{n}$ & $\vec{i}$ & $\begin{array}{l}\hat{\infty} \\
\hat{b}\end{array}$ & $\begin{array}{l}\stackrel{\wp}{\sim} \\
\stackrel{\sim}{\sigma}\end{array}$ & 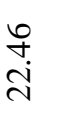 \\
\hline & \multicolumn{2}{|c|}{$\mathrm{p} \leq 0.001$} & \multicolumn{2}{|c|}{$\mathrm{p} \leq 0.05$} & \multicolumn{2}{|c|}{$\mathrm{p} \leq 0.05$} & \multicolumn{2}{|c|}{$\mathrm{p} \leq 0.05$} & \multicolumn{2}{|c|}{$\mathrm{p} \leq 0.001$} & \multicolumn{2}{|c|}{$\mathrm{p} \leq 0.001$} \\
\hline$=$ & $\begin{array}{l}n \\
0 \\
\dot{v} \\
\underline{v} \\
2\end{array}$ & 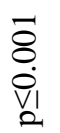 & $\begin{array}{l}\overline{8} \\
\dot{8} \\
\dot{v} \\
0\end{array}$ & $\begin{array}{l}2 \\
0 \\
\dot{v} \\
2 \\
2\end{array}$ & $\begin{array}{l}\overline{8} \\
\dot{8} \\
\dot{v} \\
2\end{array}$ & $\begin{array}{l}a \\
0 \\
\dot{v} \\
2\end{array}$ & $\begin{array}{l}\bar{\delta} \\
\vdots \\
\dot{\hat{v}} \\
\alpha\end{array}$ & $\begin{array}{l}n \\
\dot{0} \\
\dot{v} \\
2 \\
2\end{array}$ & $\begin{array}{l}\overline{8} \\
\dot{8} \\
\dot{v} \\
0\end{array}$ & $\begin{array}{l}\overline{0} \\
\dot{0} \\
\dot{v} \\
0\end{array}$ & $\begin{array}{l}\overline{8} \\
\dot{0} \\
\dot{v} \\
\text {. }\end{array}$ & $\begin{array}{l}\overline{8} \\
\dot{\theta} \\
\dot{v} \\
2\end{array}$ \\
\hline
\end{tabular}

Source: own processing in EmotivPRO

This method helped to better reveal the motivation of customers, to see different ways of perceiving the products. Though a focus group is a quality method and quantitative conclusions cannot be drawn on its basis, we grouped the answers from all for groups into an analytical table and used a binary approach to make a comparison of preferences (table 3 ).

There was a calm discussion in the group 1 and the participants concentrated on evaluating of the food products. There was a vivid discussion in the group 2 and the participants tried to guess the recipe of the bread to cook it at home. In the third mixed group the women took the initiative and were playful while communicating, that is why most of the men simple started to sympathize with the women and support their ideas. There was a conflict situation during the discussion in the mixed group 4 and the group got divided into two parties.

Appearance. Both men and women like the appearance of the bread more than the appearance of the chocolate.

Smell. Both women and men like the smell of the bread and not of the chocolate.

Taste. Men liked the chocolate and women the bread.

Aftertaste. The men liked the chocolate aftertaste, and the women liked the bread aftertaste.

On the basis of the data achieved with the help of the focus groups method the following results of tasting testing were obtained:

1. About the significance of taste properties of the food products. Men like dark chocolate more than women and the women like the bread more. 
2. . Weaknesses of the food products. The weakness of the bread for men was its mild taste. The weakness of the chocolate for women was the absence of the aroma and too much chili pepper.

3. What can enhance the properties of the food products. The attractiveness of the bread among the men can be enhanced by spicy ingredients or by combining it with meat dishes. And attractiveness of the chocolate among women can be increased by making it not spicy and adding mild taste supplements.

Table 3

The estimation of the main cognitive and emotional indicators of tasting the rye bread and the black chocolate by focus group method

\begin{tabular}{|c|c|c|c|c|c|c|}
\hline \multirow[b]{2}{*}{ 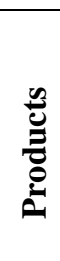 } & & \multirow[b]{2}{*}{ 岂 } & \multicolumn{4}{|c|}{ The stages of the tasting } \\
\hline & & & 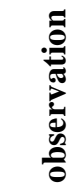 & 泡 & 总 & 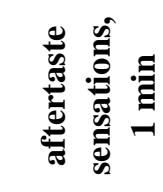 \\
\hline \multirow{8}{*}{ 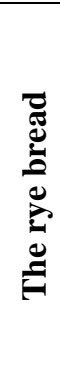 } & №1 & Men (12) & 10 & 12 & 2 & 5 \\
\hline & №2 & Women (12) & 9 & 11 & 11 & 12 \\
\hline & \multirow[t]{2}{*}{ №3 } & Men (6) & 6 & 6 & 5 & 6 \\
\hline & & Women (6) & 6 & 6 & 6 & 6 \\
\hline & \multirow[t]{2}{*}{ №4 } & Men (6) & 1 & 6 & 2 & 1 \\
\hline & & Women (6) & 6 & 5 & 4 & 3 \\
\hline & \multirow[t]{2}{*}{ Totally } & Men (24) & 17 & 24 & 9 & 12 \\
\hline & & Women (24) & 21 & 22 & 21 & 21 \\
\hline \multirow{8}{*}{ 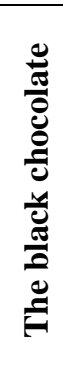 } & №1 & Men (12) & 2 & 0 & 10 & 7 \\
\hline & №2 & Women (12) & 3 & 0 & 1 & 0 \\
\hline & \multirow[t]{2}{*}{ №3 } & Men (6) & 0 & 0 & 1 & 0 \\
\hline & & Women (6) & 0 & 1 & 0 & 0 \\
\hline & \multirow[t]{2}{*}{ №4 } & Men (6) & 5 & 0 & 4 & 5 \\
\hline & & Women (6) & 0 & 1 & 2 & 3 \\
\hline & \multirow[t]{2}{*}{ Totally } & Men (24) & 7 & $\mathbf{0}$ & 15 & 12 \\
\hline & & Women (24) & 3 & 2 & 3 & 3 \\
\hline
\end{tabular}

\section{Conclusion}

1. Integral data obtained from two methods give almost the same results. Neuromarketing study takes twice as little time, but it requires a corresponding equipment, software and skills.

2. Cognitive neuromarketing specializes in measuring unconscious responses of people to stimuli in order to reveal the true attitude of the people to a certain product/service. The focus group method is very unreliable and it depends on many factors. It is important to mention that if a marketing specialists received combined data from groups 1 and 2 and also separately from the mixed groups, the conclusions would be absolutely different. However, the results taken from more groups get close to the ones obtained by neuromarketing method. Still they do not form a huge amount of data and analytics which help a marketing specialist to understand the preferences of customers faster and more professionally and to make reasonable decisions.

3. On the basis of studying food products preferences, even at the market oversaturated with proposals the outcomes of a neuromarketing study enable finding the ways to achieve an excellent result: investments are actively recouped; sales increase drastically, a brand's share at the market increases; the price of attracting new clients decreases; the frequency of times a brand is mentioned on lists of desired purchases increases; popularity of a brand rapidly goes up. 


\section{References}

1. Aldayel, M., Ykhlef, M., \& Al-Nafjan, A. (2020). Deep Learning for EEG-Based Preference Classification in Neuromarketing. Applied Sciences, 10(4), 1525.

2. Dzedzickis, A., Kaklauskas, A., \& Bucinskas, V. (2020). Human Emotion Recognition: Review of Sensors and Methods. Sensors, 20(3), 592.

3. Fathima, A., \& Vaidehi, K. (2020). Review on Facial Expression Recognition System Using Machine Learning Techniques. In Advances in Decision Sciences, Image Processing, Security and Computer Vision (pp. 608618). Springer, Cham.

4. Finch, H., \& Lewis, J. (2003). Focus groups. Qualitative research practice: A guide for social science students and researchers, 170-198.

5. Holmqvist, K., \& Andersson, R. (2017). Eye tracking: A comprehensive guide to methods, paradigms, and measures. Lund: CreateSpace Independent Publishing Platform.

6. Insight (2020). Emotiv. Retrieved from https://www.emotiv.com/insight.

7. Kamberelis, G., \& Dimitriadis, G. (2013). Focus groups. London: Routledge

8. Kenrick, D. T., \& Griskevicius, V. (2013). The Rational Animal: How Evolution Made Us Smarter Than We Think. Philadelphia: Basic Books.

9. Lewis, D. (2013). The Brain Sell: When Science Meets Shopping; How the new mind sciences and the persuasion industry are reading our thoughts, influencing our emotions, and stimulating us to shop. Hachette UK.

10. Lyapina, I. R., Uvarova, A. Y., Sibirskaya, E. V., Pashkevich, L. A., \& Tikhoykina, I. M. (2020). Cognitive Science and Neuromarketing in Behavioral Economics. In Growth Poles of the Global Economy: Emergence, Changes and Future Perspectives (pp. 925-935). Springer, Cham.

11. Maksymenko, S., Tkach, B., Lytvynchuk, L., \& Onufriieva, L. (2019). Neuro-Psycholinguistic Study of Political Slogans in Outdoor Advertising. PSYCHOLINGUISTICS, 26(1), 246-264.

12. Morin, C. (2011). Neuromarketing: the new science of consumer behavior. Society, 48(2), 131-135.

13. Phinyomark, A., Campbell, E., \& Scheme, E. (2020). Surface Electromyography (EMG) Signal Processing, Classification, and Practical Considerations. In Biomedical Signal Processing (pp. 3-29). Springer, Singapore.

14. Stewart, D. W., \& Shamdasani, P. N. (2014). Focus groups: Theory and practice (Vol. 20). Sage publications.

15. Walsh, G., Deseniss, A., \& Kilian, T. (2020). Konsumentenverhalten. In Marketing (pp. 45-104). Springer Gabler, Berlin, Heidelberg.

16. Yadava, M., Kumar, P.,Saini, R., Roy, P.P., \& Dogra, D.P. (2017). Analysis of EEG signals and its application to neuromarketing. Multimedia Tools and Applications, 76(18), 19087-19111.

17. Zurawicki, L. (2010). Neuromarketing: Exploring the brain of the consumer. Springer Science \& Business Media.

У. О. Балик, М. В. Колісник

Національний університет "Львівська політехніка"

Київська школа економіки

\section{ПОРІВНЯННЯ ПРОГНОСТИЧНОЇ ВАЛІДНОСТІ МЕТОДІВ ФОКУС-ГРУП ТА КОГНІТИВНОГО МАРКЕТИНГУ}

(C) Балик У. О., Колісник М. В., 2020

У статті розкрито актуальність та особливості застосування методів нейромаркетингу для успішного ведення бізнесу. Висвітлено можливості методу фокус-груп та сучасних досягнень когнітивного нейромаркетингу. На прикладі дегустації споживачами продуктів харчування проведено порівняльне оцінювання прогностичної валідності класичного методу маркетингу фокус-груп та новітніх методів когнітивного нейромаркетингу. Зокрема за допомогою 


\section{Balyk U. O., Kolisnyk M. V.}

використання методів когнітивного нейромаркетингу здійснено аналіз когнітивних та емоційних показників (страх, взаємодія, інтерес, хвилювання, концентрація, релаксація) учасників тестування, які отримано під час споглядання, принюхування, смакування (пережовування), стану післясмаку продуктів харчування. Це дозволило зробити висновки за гендерними відмінностями про кожен з етапів взаємодії досліджуваних $з$ продуктами харчування (зовнішній вигляд, запах, смак, післясмак). Використовуючи методи когнітивного нейромаркетингу та методи фокус-груп, проаналізовано показники учасників тестування, пов'язані з безпосереднім процесом дегустації (перебування їжі у ротовій порожнині). Унаслідок проведення нейромаркетингового дослідження було отримано великий масив даних про динаміку когнітивноемоційних показників під час споглядання, принюхування, смакування (пережовування), стану післясмаку учасників тестування. Нейромаркетингове дослідження удвічі менше забирає часу, але потребує відповідного обладнання, програмного забезпечення та навичок. На основі результатів дослідження отримано інформацію за гендерними відмінностями про значущість смакових властивостей продуктів харчування, їх слабкі сторони та можливості покращити властивості продуктів харчування. За допомогою використання методу фокус-груп окремо досліджено вплив гендеру у групі на результати дослідження. Інтегральні дані по застосуванні двох методів дають майже однакові результати.

Ключові слова: нейромаркетинг, поведінкова економіка, клієнти, метод маркетингу 